\title{
"Transformational leadership and quality of work life: A mediation model of trust climate"
}

\begin{tabular}{|c|c|}
\hline AUTHORS & $\begin{array}{l}\text { Kaniz Marium Akter (D) } \\
\text { R } \\
\text { Swee Mei Tang } \\
\text { Zurina Adnan (i) }\end{array}$ \\
\hline ARTICLE INFO & $\begin{array}{l}\text { Kaniz Marium Akter, Swee Mei Tang and Zurina Adnan (2021). Transformational } \\
\text { leadership and quality of work life: A mediation model of trust climate. Problems } \\
\text { and Perspectives in Management, 19(4), 161-174. } \\
\text { doi:10.21511/ppm.19(4).2021.14 }\end{array}$ \\
\hline DOI & http://dx.doi.org/10.21511/ppm.19(4).2021.14 \\
\hline RELEASED ON & Wednesday, 03 November 2021 \\
\hline RECEIVED ON & Saturday, 18 September 2021 \\
\hline ACCEPTED ON & Wednesday, 20 October 2021 \\
\hline LICENSE & $\begin{array}{l}(c) \text { EY } \\
\text { This work is licensed under a Creative Commons Attribution } 4.0 \text { International } \\
\text { License }\end{array}$ \\
\hline JOURNAL & "Problems and Perspectives in Management" \\
\hline ISSN PRINT & $1727-7051$ \\
\hline ISSN ONLINE & $1810-5467$ \\
\hline PUBLISHER & LLC "Consulting Publishing Company "Business Perspectives" \\
\hline FOUNDER & LLC "Consulting Publishing Company "Business Perspectives" \\
\hline$\sigma^{0}$ & $\begin{array}{l}\text { 三: } \\
\text { 三: }\end{array}$ \\
\hline NUMBER OF REFERENCES & NUMBER OF FIGURES \\
\hline 67 & 6 \\
\hline
\end{tabular}

(c) The author(s) 2021. This publication is an open access article. 


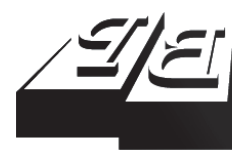

BUSINESS PERSPECTIVES

(O)

LLC "CPC "Business Perspectives"

Hryhorii Skovoroda lane, 10,

Sumy, 40022, Ukraine

www.businessperspectives.org

Received on: $18^{\text {th }}$ of September, 2021 Accepted on: $20^{\text {th }}$ of October, 2021

Published on: $3^{\text {rd }}$ of November, 2021

( Kaniz Marium Akter, Swee Mei Tang, Zurina Adnan, 2021

Kaniz Marium Akter, Ph.D. Student, Human Resource Management Department, School of Busines Management, Universiti Utara Malaysia, Malaysia. (Corresponding author)

Swee Mei Tang, Ph.D., Senior Lecturer, Human Resource Management Department, School of Business Management, Universiti Utara Malaysia, Malaysia.

Zurina Adnan, Ph.D., Senior Lecturer Human Resource Management Department, School of Busines Management, Universiti Utara Malaysia, Malaysia. MODEL OF TRUST CLIMATE

\begin{abstract}
This study aims to investigate the impact of managers' transformational leadership on employees' quality of work life through the mediation effect of firms' climate of trust in the hospitality industry. The study was conducted with operational employees working in three-star hotels in Bangladesh. Data were gathered from 186 respondents by a structured questionnaire and analyzed by SPSS 21 and SmartPLS 3.0 software. To test the hypothesized model, the study used a partial least squares structural equation model (PLS-SEM) by SmartPLS 3.0. The results of this study revealed the strong direct effects $(\mathrm{p}<.05)$ of managers' transformational leadership $(\beta=0.433)$ and firm's trust climate $(\beta=0.183)$ on the employees' quality of work life with a variance $\left(R^{2}\right)$ of $31.9 \%$, and also the significant impact of managers' transformational leadership ( $\beta=$ $0.599)$ on firm's trust climate with a variance $\left(R^{2}\right)$ of $35.9 \%$. The study also exposed a significant mediation effect $(p<.05)$ of firms' climate of trust $(\beta=0.112)$ in the relationship between managers' transformational leadership and employees' quality of work life. The findings suggest that a trust climate is such an internal mechanism that can convert transformational leadership practices into employee satisfaction with their professional life, while transformational managers can build the climate as well as enrich people's lives at work.
\end{abstract}

\section{Keywords}

JEL Classification

\section{INTRODUCTION}

Healthy life at work and satisfaction with the work life of employees have been recognized as important aspects of the firms' success (Adisa \& Gbadamosi, 2019; Dechawatanapaisal, 2017; Sari et al., 2019). Quality of work life (QWL) contributes to the service providers' happiness with their work as well as to customer satisfaction, as Burtson and Stichler (2010) indicated. An effective QWL program satisfies employee needs and humanizes jobs by enriching working conditions, thereby, quality of work life benefits employees' overall life (Sirgy et al., 2001). Thus, numerous studies have been undertaken to discover the influential factors of people's work life quality. Supervisory/managerial/leadership style and support from the managers are identified as important predictors of work life quality (Adeyemo et al., 2015; Gillet et al., 2013; Nanjundeswaraswamy \& Swamy, 2015), although these investigations are not sufficient in the service-providing industry (Kara et al., 2018), where firm's success mostly depends on employee performance.

In the intensified competition of the global market, employees who deal with diversified customer demands for attaining sustainable competitive advantage are considered key factors in the service industries. People spend an important time of their whole life for their job (Akman \& Akman, 2017), explicitly, to improve and maintain the 
firms' service quality. On the other hand, service-providing entities require self-responsive employees to ensure the highest level of customer satisfaction (Gillet et al., 2013). Research, however, indicated that employees engaged in the service industries do not enjoy their work lives that even hinders corporate performance (Eom et al., 2019; Gordon et al., 2019). Researchers accentuated transformational leadership behavior as a mechanism of management in understanding employee satisfaction in their work life quality (Akar \& Ustuner, 2019; Gillet et al., 2013; Kara et al., 2018). From the employees' point of view, they feel secured and respected at work when supervisors/managers practice transformational behaviors (Wang et al., 2011). It is a critical corporate approach to contribute to staff (skill and career) development (Bass \& Avolio, 2000; Nam \& Park, 2019), job satisfaction and retention intention (Eom et al., 2019), and their well-being (Clarke et al., 2015; Jacobs et al., 2013).

In addition to enrichment of employees' work life quality, transformational leadership has implications for creating shared and mutual trust in the organization (Lin et al., 2016). Since transformational managers articulate the charismatic vision, thereby, followers can acquire knowledge about all other people and the overall firm, which ultimately develops their self-confidence, facilitates team spirit, and creates a pleasant organizational climate (Yue et al., 2019). Besides, due to having a high concern about the followers' risks and uncertainties, transformational leaders are reliable to them (Afsar \& Masood, 2018). Furthermore, transformational behaviors produce more interactions among people that revive the notion of mutual trust (Gill \& Sypher, 2010). The charismatic influence of transformational managers builds employee trust in them and encourages people to perform beyond their expectations, consequently, when managers observe this, it also builds managers' trust in the workforce (Sun et al., 2014). However, shared and mutual trust among employees and managers contributes to the enrichment of employees' work life (Cascio, 1992; Shaw, 2005).

Previous studies emphasized the role of transformational leadership and trust (Li et al., 2019; Lin et al., 2016; Yue et al., 2019), although they do not provide enough idea of how managers' transformational leadership behaviors and firm's climate of trust (CT) could jointly impact the subordinates' work life. These multiple practices of an institution might have different impacts on individuals' work life, if they are taken together. Besides, there is a lack of understanding about the consequence of transformational leadership, when a firm practices transformational behaviors to enrich employees' work lives through developing a trust climate inside the organization. Moreover, only a few studies focused on employees' work life issues in the hospitality industry, more specifically, in the developing and under-developed country context.

The work life experience of hospitality employees is not satisfactory (Gordon et al., 2019) since they are engaged for long working hours and irregular shift works while having job insecurity too (Arefin et al., 2020; Gordon et al., 2019). In these work settings, hospitality people can not even balance their family/personal life and professional life that adversely affects their performance. The hospitality industry, therefore, faces the challenge of high employee turnover that results in high labor (turnover) costs, which is burdensome for the firms (Arefin et al., 2020; Eom et al., 2019).

\section{LITERATURE REVIEW AND HYPOTHESES}

\subsection{Transformational leadership}

The transformational leadership theory defines a transformational leader who "seeks to satisfy higher needs and engages the full potential of the follower" (Burns, 1978). The leader inspires and supports followers' skills and abilities, builds their confidence, and aligns the organizational goals with the followers' (personal) interests (Bass, 1985). A transformational leader has a high level of competence and vision to achieve organizational success, can motivate followers to respond enthusiastically, and is devoted to achieving the goals (Keller, 2006). When a leader performs transformational behaviors, s/he can positively affect the followers' self-efficacy to do a task, which in 
turn boosts people's well-being (Eom et al., 2019). Numerous studies have inspected the impacts of transformational leadership and found it to be positively linked to employee outcomes, for instance, work engagement (Valldeneu et al., 2021), work behavior (Supriyanto et al., 2020), and job performance (Donkor et al., 2021). The reason behind these favorable effects may be the fact that when a transformational leader communicates the organizational vision(s) to the followers, they can realize how their presence (contributions) are strategically important to the organizational performance which leads to their organizational behavior and job performance.

\subsection{Quality of work life}

The term 'quality of work life' for the first time was pointed out by Walton (1975), as the quality of human experience at the workplace. At that time, the QWL program was intended to improve the work environment, while employer-employee relations and product quality were emphasized for attaining a competitive advantage. Considering these issues, Walton (1975) defined QWL as an organizational process of introducing and implementing mechanisms that allow people to actively participate in organizational decisions for designing their work lives. Early in the new century, Sirgy et al. (2001) defined the concept QWL as "employee satisfaction with a variety of needs through resources, activities, and outcomes stemming from participation in the workplace". This definition emphasizes the quality of an individual's overall (work and non-work) life. Other experts also support the term 'quality of overall life', for example, Martel and Dupuis (2006) explained QWL as the association between the job factors and the quality of an individual's life.

In recent times, researchers explained QWL as employees' comfort feeling at the workplace (Hermawati et al., 2019; Monzani et al., 2016; Nayak \& Sahoo, 2015), and also the degree of happiness that comes from their career (Kiriago \& Bwisa, 2013; Wisnom \& Gallagher, 2018). Thus, industrial psychologists and management specialists commonly agreed that QWL is all about employee wellbeing. Kwahar and Iyortsuun (2018) opined that the definition of QWL depends on the industry nature and the firm's working environment, thereby, they explained QWL, in the hospitality industry context, as the way of humanization of the work environment in terms of job characteristics, physical work settings, social relationships, remuneration and benefits, management systems, and employee relations.

\subsection{Transformational leadership and quality of work life}

The literature on the impacts of transformational leadership that focus on employee outcomes is also growing. Jurado et al. (2018), for instance, exposed the importance of transformational leadership styles for promoting employee wellbeing in the healthcare sector. Similarly, in the ICT sector, Jacobs et al. (2013) found that transformational leaders communicate the meaningfulness of the job to the employees that facilitate employee wellbeing. Transformational leadership behaviors are also found associated with IT professionals' work life, job satisfaction, and retention intension (Eom et al., 2019). Accumulated evidence demonstrates the positive association of transformational leadership with the aspects of people's work life quality. However, the knowledge about the "black-box" through which transformational leadership influences employee happiness with their work life is not adequate.

Past studies have investigated the impact of transformational leadership on the firm as well as employee outcomes through different intervening factors to explore the internal mechanisms of this construct. For instance, Munir et al. (2012) indicated the mediation effect of work-life conflict between transformational leadership style and psychological wellbeing of the Danish healthcare personnel. Another study revealed the intervening role of organizational justice and organizational support between the administrators' transformational leadership behavior and faculties' quality of work life in the educational institutions (Akar \& Ustuner, 2019). Furthermore, Lin et al. (2016) exposed the mediation effect of trust climate of the top management team between CEOs' transformational leadership and team performance in the Vietnamese economy. Upon considering the work life issues of hospitality employees, the present study expects that firm's climate of trust can mediate the aforesaid relationship. 


\subsection{Climate of trust}

Organizational climate is meant by the collective perceptions of people about the working policies and practices, and the expected type of behavior at the workplace (Schneider et al., 2013). According to Bass's (1985) assumption of the outcomes of transformational leadership behaviors, this study emphasizes trust climate. Trust means believing and expecting that other person(s) will perform a specific function for the trustor when monitoring and controlling their actions are not possible (Mayer et al., 1995). As for the climate of trust, it is "the aggregate perception of trustworthiness that team members have about one another" (Langfred, 2004). In the trust climate research, several organizational outcomes have been observed such as job security (Jiang \& Probst, 2015), employee relations (Sahoo \& Sahoo, 2019), firm performance (Lin et al., 2016), and corporate competitive advantage (Fainshmidt \& Frazier, 2017). Moreover, climate of trust is positively associated with employee-focused outcomes, for instance, job satisfaction (Flaherty \& Pappas, 2000) and employee wellbeing (Leat \& El-Kot, 2009), while it is negatively linked to employees' turnover intention and burnout (Jiang \& Probst, 2015).

\subsection{Climate of trust as a mediator}

Transformational leaders encourage individuals in moving out of their comfort zones and solving challenges in novel ways, which can expose people to new cognitive domains and enhance shared ideas of mutual trust (Schaubroeck et al., 2011). However, research on the effectiveness of leadership has undoubtedly given less attention to the importance of trust climate than it might have, although transformational leaders generate and nurture mutual trust among the organizational members (Bass, 1985). In a recent study, the climate of trust has been observed as one of the fundamental organizational factors in terms of the relations between transformational leadership and positive team outcomes (Lin et al., 2016). Therefore, more investigations into the impact of transformational leadership on trust climate and the impact of trust climate on employee outcomes are necessary. Provided that, trust climate has been established as an obvious outcome of transformational leadership practices as well as a significant predictor of team members' optimal functioning. Thus, this study proposes that climate of trust can be an intervening factor between managers' transformational leadership and personnel's quality of work life.

\subsection{Theoretical framework and hypotheses}

The theoretical framework of the current study is proposed based on the notion of the transformational leadership theory of Burns (1978) and Bass (1985) that would illustrate the influence of transformational leadership on trust climate and quality of work life. Transformational leaders can build a supportive climate of a working team and encourage teamwork by developing trust and respect in the team members (Bass et al., 1987; Isaksen, 1983). Through utilizing a large and diverse set of samples, scholars validated the favorable outcomes of transformational leadership on employee satisfaction (Bass, 1990; Bass \& Avolio, 1993; Pillai, 1995).

Therefore, this study proposes a research model (Figure 1) that would provide new insights in building a climate of trust in the organization and enriching staffs' work life quality. This study intends to empirically examine the proposed research model by testing the following hypotheses:

H1: Transformational leadership has a positive impact on the quality of work life.

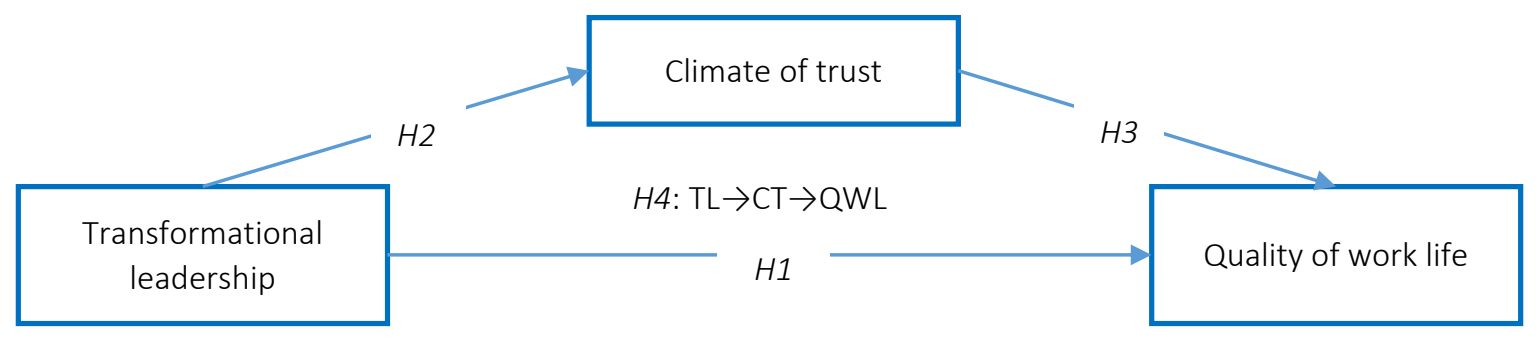

Figure 1. Research model 
H2: Transformational leadership has a positive impact on climate of trust.

H3: Climate of trust has a positive impact on the quality of work life.

H4: Climate of trust has a mediation effect in the relationship between transformational leadership and the quality of work life.

\section{METHODS}

In this study, a cross-sectional survey was undertaken through a self-administered questionnaire containing 45 items adapted from the previously established scales. To measure the quality of work life, thirty-four items were taken from Kwahar and Iyortsuun (2018). The construct transformational leadership was measured by seven items of Bass and Avolio (2000). Finally, four items were taken from Huff and Kelley (2003) for measuring the climate of trust. Responses were collected on a five-point Likert scale (1 represents "strongly disagree" and 5 represents "strongly agree").

300 questionnaires were delivered among the fulltime operational employees of the three-star hotels in Bangladesh during May-June 2021. In all, 197 filled-up questionnaires were returned, while 11 were dropped due to incompleteness, and finally, 186 responses were accepted for analysis with a response rate of $62 \%$.

The collected data were processed and analyzed by SPSS version 21 and SmartPLS 3.0 software. Respondents' demographic profiles and the descriptive statistics of the study variables were analyzed by SPSS 21. Afterward, this study assessed the measurement model and structural model using PLS procedures. Furthermore, to test the hypotheses and observe the mediation effect, a bootstrapping function (2,000 resamples) was generated using SmartPLS 3.0.

\section{RESULTS}

\subsection{Demographic analysis}

The sample $(n=186)$ of the current study consisted of about $66.7 \%$ male and $33.3 \%$ female re- spondents. Respondents mostly were in the 35-44 age group (37.1\%), followed by the 25-34 group (35.5\%), 18-24 group (17.2\%), 45-54 group (9.7\%), and 55-65 group (0.5\%). The majority of the respondents were married (68.8\%), whereas $22.6 \%$ were unmarried, $3.2 \%$ were separated, $4.3 \%$ were widowed and $1.1 \%$ were divorced. In terms of education, most respondents had graduation (48.3\%), while $25.3 \%$ had post-graduation, $22.6 \%$ had professional certification (diploma, etc.), and $3.8 \%$ had a higher secondary certificate. The respondents were engaged in various operational divisions, such as housekeeping (30.6\%), food and beverage production (17.2\%), food and beverage service (31.2\%), leisure and lifestyle (12.4\%), and the front office (8.6\%). In terms of categories of the respondents' positions, $11.3 \%$ were holding assistant manager level positions, $25.2 \%$ executive-level positions, $28 \%$ supervisor level positions, and $35.5 \%$ rank-and-file level positions. Among the respondents, the largest group (40.9\%) had 6 to 10 years of job experience, while $28 \%$ had 1 to 5 years, $21.5 \%$ had 11 to 15 years, and $9.7 \%$ had more than 15-years of job experience.

\subsection{Descriptive and correlation analysis}

The score of mean and standard deviation represents the general perceptions of the respondents. For this reason, this study conducted a descriptive analysis to obtain the scores of the mean and standard deviation of each construct (quality of work life, transformational leadership, climate of trust). Since the responses were measured on a fivepoint scale, a mean score nearer to five is termed as high agreement, whereas low agreement is meant if the score is nearer to one. In this study, for all three constructs, the mean score was above 3 that indicates the consistency of the results. Furthermore, the dispersion value for all the variables was lower than 1 , which was the desired result of the study.

This study also performed a correlation analysis to observe the coefficients between the quality of work life, transformational leadership, and climate of trust. The correlation coefficients confirmed that the variables are significantly correlated $(p<0.01)$ with each other. The scores of mean, standard deviation, and correlation are displayed in Table 1. 
Table 1. Mean, standard deviation, and correlation coefficients

\begin{tabular}{l|c:c:c:c:c}
\hline \multicolumn{1}{c}{ Constructs } & Mean & SD & QWL & TL & CT \\
\hline Quality of work life & 3.129 & 0.795 & 1 & & \\
\hdashline $\begin{array}{l}\text { Transformational } \\
\text { leadership }\end{array}$ & 3.231 & 0.763 & $0.521^{*}$ & 1 & \\
\hdashline Climate of trust & 3.345 & 0.758 & $0.429^{* *}$ & $0.586^{* *}$ & 1 \\
\hline
\end{tabular}

Note: ${ }^{* *}$ means the correlation is significant at the 0.01 level (1-tailed).

\subsection{Measurement model assessment}

To assess the reliability and validity of the measurement scales of the constructs, confirmatory factor analysis was carried out. The values of the measurement model are presented in Table 2 and Table 3.

\subsubsection{Convergent validity}

As suggested by Chin (1998), the factor loadings, composite reliability (CR), Cronbach's alpha $(\alpha)$, and average variance extracted (AVE) are used for assessing the convergent validity. Table 2 (Figure 2) exhibits the scores of CR, $a$, and AVE of all the constructs. The factor loadings above the recommended value of 0.6 were retained (Chin, 1998). Thus, the items QWL2, QWL21, QWL27, QWL30, and QWL33 with low loadings were subsequently dropped from the model (see Appendix A). Moreover, CR and $\alpha$ met the minimum cut-off values (0.7), and AVE was higher than 0.5 for all the constructs. Thus, the results determined that the constructs met the requirement of reliability and convergent validity (Fornell \& Larcker, 1981).

Table 2. Reliability and convergent validity

\begin{tabular}{l|c:c:c}
\hline \multicolumn{1}{c}{ Construct } & $\boldsymbol{\alpha}$ & CR & AVE \\
\hline Quality of work life & 0.972 & 0.974 & 0.567 \\
\hline $\begin{array}{l}\text { Transformational } \\
\text { leadership }\end{array}$ & 0.912 & 0.930 & 0.655 \\
\hdashline Climate of trust & 0.865 & 0.908 & 0.712 \\
\hline
\end{tabular}

\subsubsection{Discriminant validity}

This study subsequently evaluated the discriminant validity of the model using the indicators' cross-loadings and the Fornell-Larcker criterion, as of Hair et

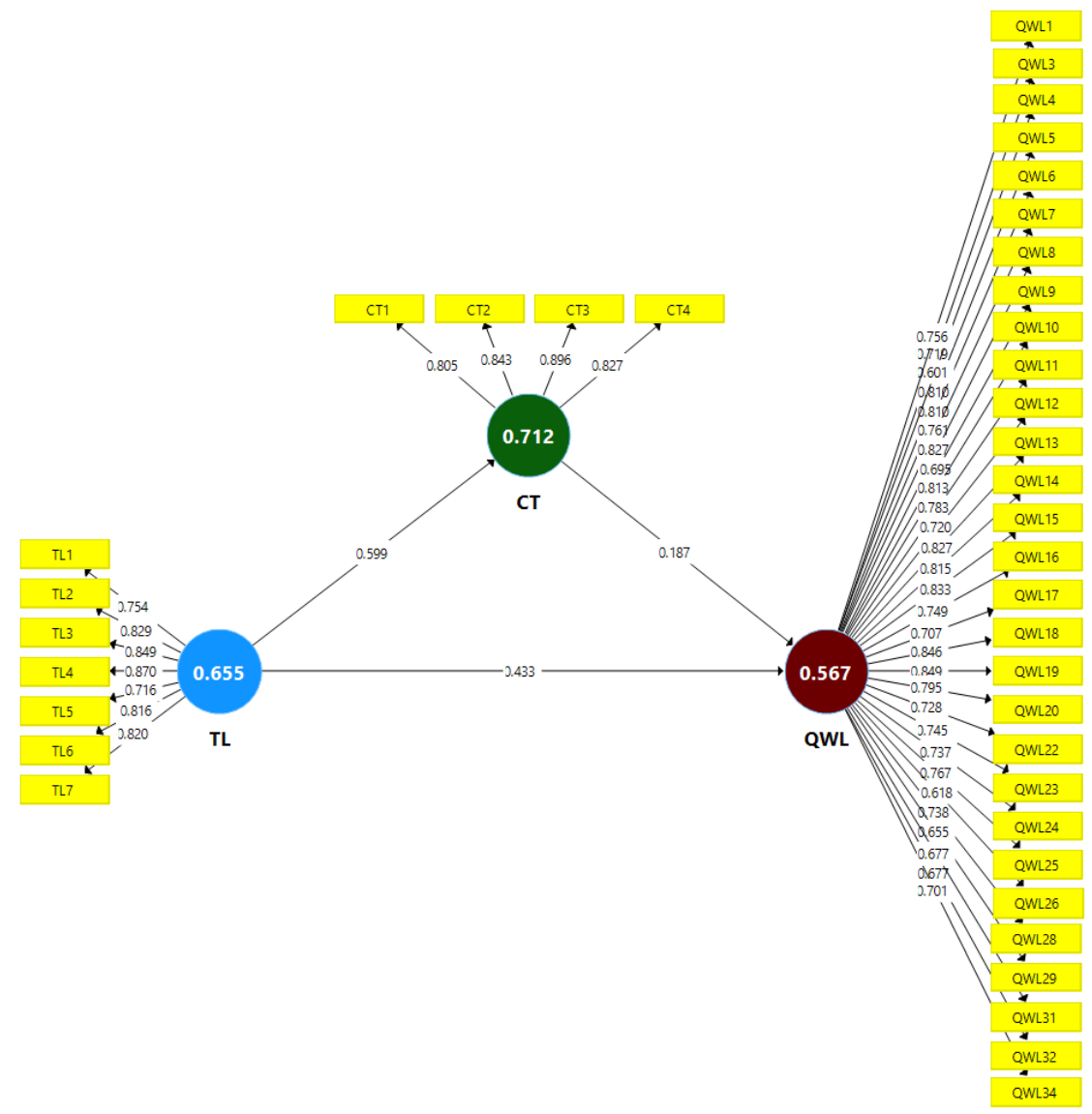

Figure 2. Measurement model 
al.s (2017) suggestion. The cross-loading results indicated that the outer loadings of all the indicators with their corresponding constructs were greater than the cross-loadings with other constructs (see Appendix A). In addition, as per the suggestion of Fornell and Larcker's (1981) criteria, the correlations between the constructs and the square root of AVE of all the constructs were compared. Results exhibited (Table 3) that the square root of AVE (diagonal) was higher than the correlation (off-diagonal) of each construct, which indicated that all the constructs display necessary discriminant validity (Hair et al., 2017). Therefore, the measurement model is considered satisfactory.

Table 3. Discriminant validity

\begin{tabular}{l|c:c:c}
\hline \multicolumn{1}{c}{ Construct } & QWL & TL & CT \\
\hline Quality of work life & $(0.753)$ & & \\
\hdashline Transformational leadership & 0.545 & $(0.809)$ & \\
\hdashline Climate of trust & 0.446 & 0.599 & $(0.844)$ \\
\hline
\end{tabular}

Note: Values in parentheses represent the square root of AVE, and other entries represent the correlations.

\subsection{Structural equation model analysis}

The hypotheses were tested using the bootstrapping function with 2,000 bootstrap samples and the results were exhibited in Table 4. Based on the assessment of the path coefficients (referring to Figure 2 and Figure 3), the two hypothesized relationships $H 1(t=5.686)$, and $H 3(t=1.935)$ were found to have a t-value above 1.645 (one-tailed), thus significant at 0.05 level of significance (Hair et al., 2017). Specifically, hypothesis $1(\beta=0.433$, $p<0.05)$ indicated that transformational leadership strongly impacts the quality of work life. Similarly, the result of hypothesis 3 also showed that climate of trust $(\beta=0.187, p<0.05)$ has a significant influence on the quality of work life. Thus, $H 1$ and $H 3$ were accepted. The results suggested that both transformational leadership and climate of trust have significant direct effects on the quality of work life. Both the exogenous constructs explained $31.9 \%$ of the variance in quality of work life. The value of $R^{2}(0.319)$ was greater than 0.26 indicating a substantial model (Cohen, 1988).

Furthermore, in support of hypothesis 2, the result exposed that transformational leadership $(\beta=0.599, t=11.234, p<0.05)$ has a considerable influence on climate of trust. So, $\mathrm{H} 2$ was also accepted. Besides, transformational leadership explained $35.9 \%$ of the variance in climate of trust. The value of $R^{2}(0.359)$ was greater than 0.26 , which indicated a substantial model, as suggested by Cohen (1988).

Finally, the result showed that the indirect effect of employee empowerment on quality of work life $(\mathrm{TL} \rightarrow \mathrm{CT} \rightarrow \mathrm{QWL})$ with $\beta=0.112(t=1.863, p<0.05)$ is significant. So, $H 4$ was accepted.

Table 4. Hypothesis testing

\begin{tabular}{|c|c|c|c|c|c|}
\hline $\begin{array}{l}\text { Hypothesized } \\
\text { relationship }\end{array}$ & $\begin{array}{l}\text { Std. } \\
\text { Beta }\end{array}$ & $\begin{array}{l}\text { Std. } \\
\text { Error }\end{array}$ & $t$-value & $p$-value & Decision \\
\hline $\mathrm{H} 1: \mathrm{TL} \rightarrow \mathrm{QWL}$ & 0.433 & 0.076 & 5.686 & $0.000 * *$ & Accepted \\
\hline H2: $\mathrm{TL} \rightarrow \mathrm{CT}$ & 0.599 & 0.053 & 11.234 & $0.000 * *$ & Accepted \\
\hline H3: $\mathrm{CT} \rightarrow \mathrm{QWL}$ & 0.187 & 0.097 & 1.935 & $0.027 * *$ & Accepted \\
\hline H4: $\mathrm{TL} \rightarrow \mathrm{CT} \rightarrow \mathrm{QWL}$ & 0.112 & 0.060 & 1.863 & $0.031^{* *}$ & Accepted \\
\hline
\end{tabular}

\subsection{Mediation effect analysis}

To verify if the climate of trust has a mediation effect in the relationship between transformational leadership and quality of work life, the indirect effects of the variables were checked using the bootstrapping function with 2,000 bootstrap samples (Table 5). Besides, the confidence intervals of the indirect path were observed (Table 5), as of Hair et al.'s (2017) recommendation. There is no zero between the confidence intervals (lower limit and upper limit) in terms of the relationship based on the $t$-value. Furthermore, the indirect and the direct effects of transformational leadership on quality of work life are found significant, it indicates that climate of trust can partially mediate the aforementioned relation (Ramayah et al., 2018).

Table 5. Mediation effect testing

\begin{tabular}{|c|c|c|c|c|c|}
\hline $\begin{array}{l}\text { Hypothesized } \\
\text { relationship }\end{array}$ & $t$-value & $p$-value & $5 \%$ LL & $95 \%$ UL & Decision \\
\hline H4: $\mathrm{TL} \rightarrow \mathrm{CT} \rightarrow \mathrm{QWL}$ & 1.863 & $0.031 * *$ & 0.018 & 0.217 & Accepted \\
\hline
\end{tabular}




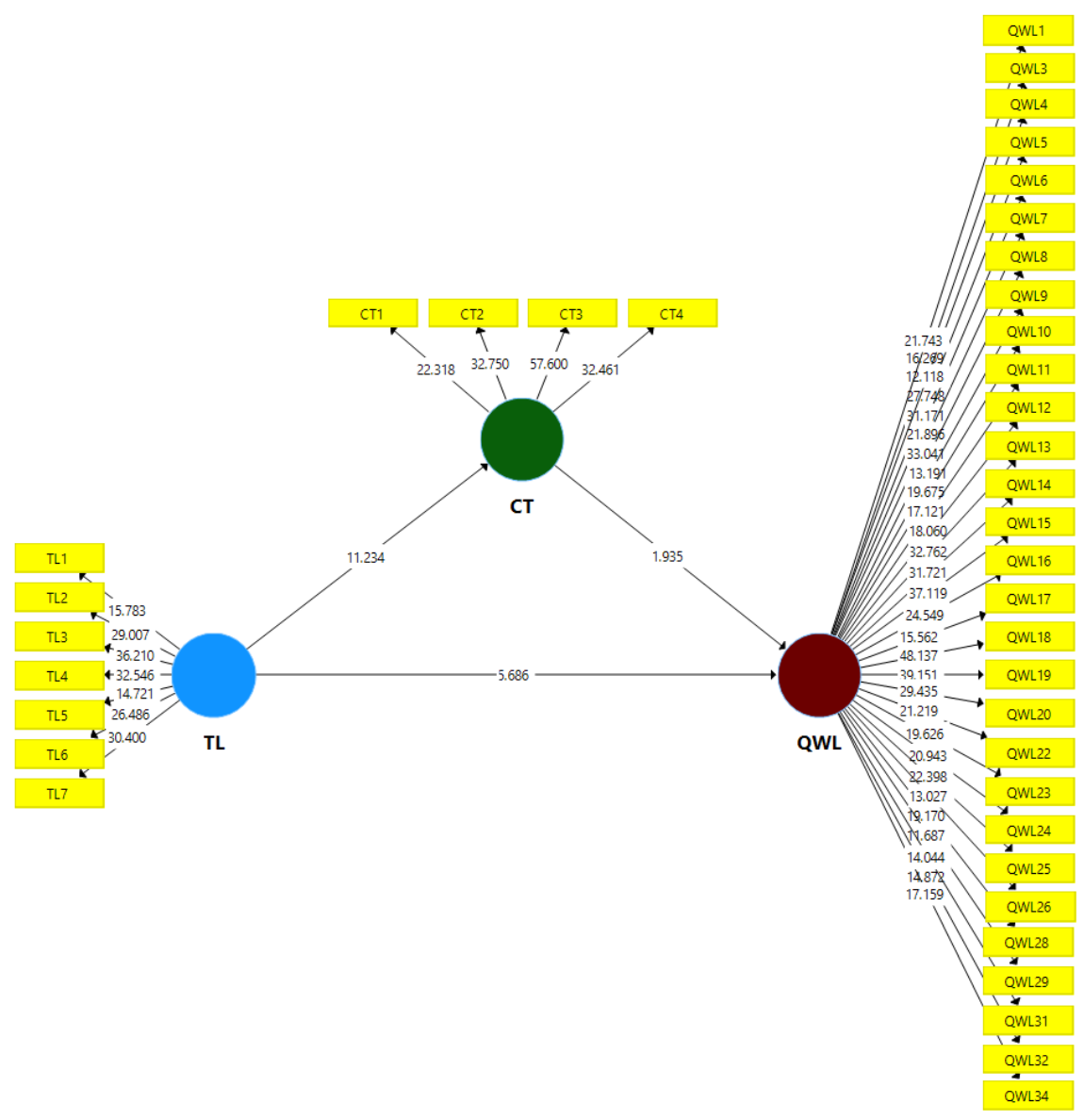

Figure 3. Bootstrapping results

\section{DISCUSSION}

The objectives of this study were to examine the impact of managers' transformational leadership on employees' quality of work life and the mediation effect of climate of trust in this relation in the context of the hospitality industry of Bangladesh. Even though prior research asserted the positive influence of different leadership styles in enriching individuals' work life quality, there is still a lack of knowledge about how the transformational leadership practices in hospitality firms affect employees' work life. Thus, this study investigates the role of hospitality firms in enhancing the quality of people's work lives. Also, based on the relevance of a firm's trust climate with transformational leadership (Li et al., 2019; Lin et al., 2016; Yue et al., 2019), this study approaches the climate of trust and questions how this climate impacts employees' work life quality.

This study conducted a cross-sectional survey among the operational employees engaged in the three-star hotels of Bangladesh. The results pre- sented four major findings that are aligned with the hypotheses of this study. Firstly, the results confirmed that transformational leadership (H1) has a strong effect on the quality of work life. The finding is consistent with the literature revealing that transformational leadership enriches employees' work life quality (Eom et al., 2019; Gillet et al., 2013; Kara et al., 2018). These studies exhibited how the practices of transformational leadership stimulate employee happiness in their life at work. Secondly, a significant influence of transformational leadership on the firm's trust climate (H2) was found in this study. This finding supports the previous similar studies that highlighted transformational leadership as a predictor of a climate of shared and mutual trust at the workplace (Li et al., 2019; Lin et al., 2016; Yue et al., 2019). Transformational leaders care for employees, reduce their risks and uncertainties, and boost their self-confidence, thereby, employees confidently rely on the managers and also on others. That is how a climate of trust is generated in a firm that nurtures people's trust. Thirdly, the result of this 
study revealed hospitality firms' trust climate $(H 3)$ as a strong predictor of the quality of work life of people. This finding corroborates previous similar study findings (Blömeke et al., 2015; Jiang \& Probst, 2015; Sale, 2006; Van der Berg \& Martins, 2013). A working environment having a high degree of shared and mutual trust creates employee happiness at work and satisfaction in work life.

Finally, the study found (H4) the mediation effect of trust climate in the relationship between transformational leadership and quality of work life. The direct effect (TL $\rightarrow$ QWL) of transformational leadership on quality of work life was ( $t=$ 5.686, $p=0.000)$ significant and the indirect effect $(\mathrm{TL} \rightarrow \mathrm{CT} \rightarrow \mathrm{QWL})$ was also $(t=1.863, p=0.031)$ significant. It indicated that climate of trust absorbed only part of the direct effects of transformational leadership. When both the effects of a variable on another variable are significant, it represents partial mediation (Ramayah et al., 2018). So, the mediation effect of climate of trust was partial in the relationship between transformational leadership and quality of work life. It has been found that the climate of trust mediates the relationship between organizational justice, conflict management, and employee relations (Sahoo \& Sahoo, 2019), and the relationship between transformational leadership and corporate success (Lin et al., 2016). The finding of the present study supports the results of these prior studies (Lin et al., 2016; Sahoo \& Sahoo, 2019).

This study contributes to the transformational leadership theory. Since, transformational leadership influences a firm's trust climate that further impacts employees' work life, managers need to design effective transformational leadership practices that will improve employee perceptions of life at work. Moreover, the study findings suggest that hospitality firms' transformational leadership is one of the dominating areas that can contribute to employees' work life as well as the firm's trust climate. By the tenets of an organization, this study asserts that hospitality employees are independently responsive personnel when they get proper supervision and caring from their leaders. Additionally, the elements of transformational leadership contribute to the employees' work life as well as personal life quality. The findings also suggest that people's work life quality is not only dependent on organizational success, but it also depends on a hospitality firm's endeavors and managers' intentions to take care of the satisfaction and wellness of its workforce. Therefore, this study establishes a critical aspect of company-initiated antecedents for multifaceted satisfaction outcomes of hospitality employees.

\section{CONCLUSION}

The study explains the impact of transformational leadership on the quality of work life, and exposes the mediation effect of trust climate on the aforementioned relationship of the hospitality personnel in the developing country context. Results indicate the positive impact of transformational leadership on the quality of work life, and the presence of mediation effect of trust climate in that relationship. These findings suggest the managers to practice the transformational leadership style for supervising the working people and to develop a climate of mutual trust where everybody can depend on others' trustworthiness. By emphasizing these practices, firms can reinforce employee wellbeing, balanced work life, mutual respect, and job satisfaction. On the other hand, when managers practice transformational behaviors in all aspects of subordinates and build a climate with a high level of shared and mutual trust, the quality of work life enhances and individuals' satisfaction with life at work improves in consequence. Thus, people will be motivated to be creative and they will perform their extra-role behavior and meet the new challenges at work that will ultimately cause the accomplishment of sustainable corporate success.

This study attempts to indicate the organizational/managerial functions that can enrich employee perception toward the work and work life as well. Since people are critical assets in the hospitality industry, they need a peaceful work life that can be ensured by proper care and value. Therefore, the present study offers an original and meaningful perspective through an empirical validation in improving the existing knowledge of the quality of work life with the integration of transformational leadership and climate of trust in the hospitality industry of Bangladesh. 
This study also has some limitations. Firstly, the study was undertaken in three-star hotels. Thus, its scope could be extended in future research by incorporating diverse hospitality firms. Secondly, the study took into consideration a single country (Bangladesh). Future studies would consider the multi-country (developed, developing, and under-developed countries) context to validate the proposed research model because managerial practices in employee issues can vary substantially country-to-country. Thirdly, the study findings shed light on the relevance of employee satisfaction in terms of their work life quality. Future research would investigate the organizational conditions that could assist or hamper the improvement of qualities of employees' work life. Finally, the proposed research model would include employees' socioeconomic status and job characteristics as the moderating variable in future analysis that may offer new perspectives.

\section{AUTHOR CONTRIBUTIONS}

Conceptualization: Kaniz Marium Akter, Swee Mei Tang, Zurina Adnan.

Data curation: Kaniz Marium Akter.

Formal analysis: Kaniz Marium Akter.

Funding acquisition: Kaniz Marium Akter.

Investigation: Kaniz Marium Akter.

Methodology: Kaniz Marium Akter, Swee Mei Tang, Zurina Adnan.

Project administration: Kaniz Marium Akter.

Resources: Kaniz Marium Akter.

Software: Kaniz Marium Akter.

Supervision: Kaniz Marium Akter, Swee Mei Tang, Zurina Adnan.

Validation: Kaniz Marium Akter, Swee Mei Tang, Zurina Adnan.

Visualization: Kaniz Marium Akter.

Writing - original draft: Kaniz Marium Akter.

Writing - review \& editing: Kaniz Marium Akter, Swee Mei Tang, Zurina Adnan.

\section{REFERENCES}

1. Adeyemo, D. A., Dzever, L. T., \& Lambert, N. J. (2015). Organizational climate, leadership style and emotional intelligence as predictors of quality of work life among bank workers in Ibadan, Nigeria. European Scientific Journal, 11(4). Retrieved from https://core.ac.uk/reader/236406230

2. Adisa, T. A., \& Gbadamosi, G. (2019). Regional crises and corruption: the eclipse of the quality of working life in Nigeria. Employee Relations, 41(3), 571-591. https://doi.org/10.1108/ER-022018-0043

3. Afsar, B., \& Masood, M. (2018). Transformational leadership, creative self-efficacy, trust in supervisor, uncertainty avoidance, and innovative work behavior of nurses. The Journal of Applied Behavioral Science,

54(1), 36-61. http://dx.doi.

org/10.1177/0021886317711891

4. Akar, H., \& Ustuner, M. (2019). The Relationships between Perceptions of Teachers' Transformational Leadership, Organizational Justice, Organizational Support and Quality of Work Life. International Journal of Research in Education and Science, 5(1), 309-322. Retrieved from https:// www.researchgate.net/publication/329253521_The_Relationships_between_Perceptions_of_ Teachers'_Transformational_ Leadership_Organizational_Justice_Organizational_Support_and_ Quality_of_Work_Life

5. Akman, Y., \& Akman, G. İ. (2017). The Effect of the Perception of Primary School Teachers' Quality of Work Life on Work
Engagement. Elementary Education Online, 16(4), 14911504. http://dx.doi.org/10.17051/ ilkonline.2017.342971

6. Arefin, M. S., Alam, M. S., Islam, N., \& Molasy, M. (2020). Organizational politics and workfamily conflict: the hospitality industry in Bangladesh. South Asian Journal of Business Studies, 9(3), 357-372. https://doi. org/10.1108/SAJBS-07-2019-0135

7. Bass, B. M. (1985). Leadership and performance beyond expectation. New York: Free Press.

8. Bass, B. M. (1990). From transactional to transformational leadership: learning to share the vision. Organizational Dynamics, 18(3), 19-31. https://doi. org/10.1016/0090-2616(90)90061-S

9. Bass, B. M., \& Avolio, B. J. (1993). Transformational leadership and 
organizational culture. Public administration quarterly, 17(1), 112-121. Retrieved from https:// www.jstor.org/stable/40862298

10. Bass, B. M., \& Avolio, B. J. (2000). MLQ: Multifactor Leadership Questionnaire Technical Report. Thousand Oaks, CA: Sage Publications.

11. Bass, B. M., Waldman, D. A., Avolio, B. J., \& Bebb, M. (1987). Transformational leadership and the falling dominoes effect. Group and Organization Management, 12(1), 73-87. https://doi. org/10.1177/105960118701200106

12. Blömeke, S., Hoth, J., Döhrmann, M., Busse, A., Kaiser, G., \& König, J. (2015). Teacher change during induction: Development of beginning primary teachers' knowledge, beliefs and performance. International Journal of Science and Mathematics Education, 13(2), 287-308. http:// dx.doi.org/10.1007/s10763-0159619-4

13. Burns, J. M. (1978). Leadership. New York: Harper \& Row.

14. Burtson, P. L., \& Stichler, J. F. (2010). Nursing work environment and nurse caring: relationship among motivational factors. Journal of Advanced Nursing Research, 66(8), 18191831. https://doi.org/10.1111/ j.1365-2648.2010.05336.x

15. Cascio, W. F. (1992). Managing Human Resources: Productivity, Quality of Worklife, Profit ( $3^{\text {rd }}$ ed.). New York: McGraw Hill.

16. Chin, W. (1998). Issues and opinion on structural equation modelling. MIS Quarterly, 22(1), 7-16. Retrieved from https://www. jstor.org/stable/249674

17. Clarke, H. M., Arnold, K. A., \& Connelly, C. E. (2015). Improving follower well-being with transformational leadership. In S. Joseph (Ed.), Positive psychology in practice: Promoting human flourishing in work, health, education, and everyday life (pp. 341-356). http://dx.doi. org/10.1002/9781118996874.ch21

18. Cohen, J. (1988). Statistical power analysis for the behavioral sciences
( $2^{\text {nd }}$ ed.). Hillsdale, NJ: Lawrence Erlbaum Associates.

19. Dechawatanapaisal, D. (2017). The mediating role of organizational embeddedness on the relationship between quality of work life and turnover: Perspectives from healthcare professionals. International Journal of Manpower, 38(5), 696-711. http://dx.doi. org/10.1108/IJM-12-2015-0205

20. Donkor, F., Dongmei, Z., \& Sekyere, I. (2021). The Mediating Effects of Organizational Commitment on Leadership Styles and Employee Performance in SOEs in Ghana: A Structural Equation Modeling Analysis. SAGE Open. https://doi.org/10.117 7\%2F21582440211008894

21. Eom, M., Gudigantala, N., \& Kim, Y. J. (2019). Investigating the Process of Developing and Retaining Competent IT Personnel: The Role of IT Leadership. Asia Pacific Journal of Information Systems, 29(1), 83116. Retrieved from https://www. earticle.net/Article/A350490

22. Fainshmidt, S., \& Frazier, M. L. (2017). What facilitates dynamic capabilities? The role of organizational climate for trust. Long Range Planning, 50(5), 550-566. https://doi.org/10.1016/j. lrp.2016.05.005

23. Flaherty, K. E., \& Pappas, J. M. (2000). The role of trust in salesperson - sales manager relationships. Journal of Personal Selling \& Sales Management, 20(4), 271-278. Retrieved from https:// www.tandfonline.com/doi/abs/10. 1080/08853134.2000.10754247

24. Fornell, C., \& Larcker, D. (1981). Evaluating structural equation models with unobservable variables and measurement errors. Journal of Marketing Research, 18(1), 39-50. https://doi. org/10.1177/002224378101800104

25. Gill, M. J., \& Sypher, B. D. (2010). Workplace incivility and organizational trust. In P. Lutgen-Sandvik, \& B. D. Sypher (Eds.), Destructive Organizational Communication: Processes, consequences, and constructive ways of organizing (pp. 69-90). Taylor \& Francis Group.

26. Gillet, N., Fouquereau, E., Bonnaud-Antignac, A. Mokounkolo, R., \& Colombat, P. (2013). The mediating role of organizational justice in the relationship between transformational leadership and nurses' quality of work life: A cross-sectional questionnaire survey. International journal of nursing studies, 50(10), 13591367. https://doi.org/10.1016/j. ijnurstu.2012.12.012

27. Gordon, S., Tang, C. H., Day, J., \& Adler, H. (2019). Supervisor support and turnover in hotels: Does subjective well-being mediate the relationship? International Journal of Contemporary Hospitality Management, 31(1), 496512. https://doi.org/10.1108/ IJCHM-10-2016-0565

28. Hair, J. F., Hult, G. T. M., Ringle, C., \& Sarstedt, M. (2017). A primer on partial least squares structural equation modeling (PLS-SEM). USA: Sage publications Inc.

29. Hermawati, A., Suhermin, \& Puji, R. (2019). The transglobal leadership-based strategy of MSMEs performance optimization of Malang Raya and the implementation of quality of work life. Research Journal of Textile and Apparel, 23(1), 38-57. https://doi.org/10.1108/RJTA-052018-0038

30. Huff, L., \& Kelley, L. (2003). Levels of organizational trust in individualist versus collectivist societies: A seven-nation study. Organization Science, 14(1), 81-90. https://doi.org/10.1287/ orsc.14.1.81.12807

31. Isaksen, S. G. (1983). Toward a model for the facilitation of creative problem solving. The Journal of Creative Behavior, 17(1), 18-31. https://doi. org/10.1002/j.2162-6057.1983. tb00971.x

32. Jacobs, C., Pfaff, H., Lehner, B., Driller, E., Nitzsche, A., Stieler-Lorenz, B., Wasem, J., \& Jung, J. (2013). The influence of transformational leadership 
on employee wellbeing: Results from a survey of companies in the information and communication technology sector in Germany. Journal of occupational and environmental medicine, 55(7), 772-778. http://dx.doi.org/10.1097/ JOM.0b013e3182972ee5

33. Jiang, L., \& Probst, T. M. (2015). Do your employees (collectively) trust you? The importance of trust climate beyond individual trust. Scandinavian Journal of Management, 31(4), 526-535. https://doi.org/10.1016/j.scaman.2015.09.003

34. Jurado, M. M., Pérez-Fuentes, M., Gázquez Linares, J., Simón Márquez, M., \& Martos Martínez, Á. (2018). Burnout risk and protection factors in certified nursing aides. International journal of environmental research and public health, 15(6), 11161124. http://dx.doi.org/10.3390/ ijerph15061116

35. Kara, D., Kim, H., Lee, G., \& Uysal, M. (2018). The moderating effects of gender and income between leadership and quality of work life (QWL). International Journal of Contemporary Hospitality Management, 30(3), 1419-1435. http://dx.doi.org/10.1108/ IJCHM-09-2016-0514

36. Keller, R. T. (2006). Transformational leadership, initiating structure, and substitutes for leadership: A longitudinal study of research and development project team performance. Journal of Applied Psychology, 91(1), 202-210. https://doi.org/10.1037/00219010.91.1.202

37. Kiriago, A. N., \& Bwisa, H. M. (2013). Working Environment Factors that Affect Quality of Work Life among Attendants in Petrol Stations in Kitale Town in Kenya. International Journal of Academic Research in Business and Social Sciences, 3(5), 289-296.

38. Kwahar, N., \& Iyortsuun, A. S. (2018). Determining the Underlying Dimensions of Quality of Work Life (QWL) in the Nigerian Hotel Industry. Entrepreneurial Business and
Economics Review, 6(1), 53-70. http://dx.doi.org/10.15678/ EBER.2018.060103

39. Langfred, C. W. (2004). Too much of a good thing? Negative effects of high trust and individual autonomy in self-managing teams. Academy of Management Journal, 47(3), 385-399. Retrieved from https://www.jstor.org/stable/20159588

40. Leat, M., \& El-Kot, G. (2009). Interpersonal trust at work, intrinsic motivation, work related tension and satisfaction in Egypt. International Journal of Workplace Health Management, 2(2), 180-194. http://dx.doi. org/10.1108/17538350910970237

41. Li, H., Sajjad, N., Wang, Q., Ali, A. M., Khaqan, Z., \& Amina, S. (2019). Influence of transformational leadership on employees' innovative work behavior in sustainable organizations: Test of mediation and moderation processes. Sustainability, 11(6), 1594. https:// doi.org/10.3390/su11061594

42. Lin, H. C., Dang, T. T. H., \& Liu, Y. S. (2016). CEO transformational leadership and firm performance: A moderated mediation model of TMT trust climate and environmental dynamism. Asia Pacific Journal of Management, 33(4), 981-1008. https://doi.org/10.1007/s10490016-9468-x

43. Martel, J. P., \& Dupuis, G. (2006). Quality of work life: theoretical and methodological problems, and presentation of a new model and measuring instrument. Social Indicators Research: An International and Interdisciplinary Journal for Quality-of-Life Measurement, 77(2), 333-368. Retrieved from https://ideas. repec.org/a/spr/soinre/v77y2006i2p333-368.html

44. Mayer, R. C., Davis, J. H., \& Schoorman, F. D. (1995). An integrative model of organizational trust. Academy of Management Review, 20(3), 709-734. https://doi. org/10.2307/258792
45. Monzani, L., Espí-López, G. V., Zurriaga, R., \& Andersen, L. L. (2016). Manual therapy for tension-type headache related to quality of work life and work presenteeism: Secondary analysis of a randomized controlled trial. Complementary Therapies in Medicine, 25, 86-91. https://doi. org/10.1016/j.ctim.2016.01.008

46. Munir, F., Nielsen, K., Garde, A. H., Albertsen, K., \& Carneiro, I. G. (2012). Mediating the effects of work-life conflict between transformational leadership and healthcare workers' job satisfaction and psychological wellbeing. Journal of nursing management, 20(4), 512-521. https://doi.org/10.1111/j.13652834.2011.01308.x

47. Nam, K. A., \& Park, S. (2019). Factors influencing job performance: organizational learning culture, cultural intelligence, and transformational leadership. Performance Improvement Quarterly, 32(2), 137-158. https://doi.org/10.1002/ piq. 21292

48. Nanjundeswaraswamy, T., \& Swamy, D. R. (2015). Leadership styles and quality of work life in SMEs. Management Science Letters, 5(1), 65-78. https://doi. org/10.5267/j.msl.2014.12.006

49. Nayak, T., \& Sahoo, C. K. (2015). Quality of work life and organizational performance. Journal of Health Management, 17(3), 263-273. https://doi. org/10.1177/0972063415589236

50. Patiar, A., \& Wang, Y. (2016). The effects of transformational leadership and organizational commitment on hotel departmental performance. International Journal of Contemporary Hospitality Management, 28(3), 586608. https://doi.org/10.1108/ IJCHM-01-2014-0050

51. Pillai, R. (1995). Context and charisma: The relationship of organic structure, collectivism, and crisis to charismatic leadership. Academy of Management, 1995(1). https:// doi.org/10.5465/ambpp.1995.17536616 
52. Ramayah, T., Cheah, J., Chuah, F., Ting, H., \& Memon, M. A. (2018). Partial least squares structural equation modeling (PLS-SEM) using smartPLS 3.0. Malaysia: Pearson.

53. Sahoo, R., \& Sahoo, C. K. (2019). Organizational justice, conflict management and employee relations: The mediating role of climate of trust. International Journal of Manpower, 40(4), 783799. https://doi.org/10.1108/IJM12-2017-0342

54. Sale, J. E. (2006). The experience of participatory research: Perceptions of oncology employees participating in a workplace study. Quality and Quantity, 40(6), 1037-1053. https://doi.org/10.1007/s11135005-3957-1

55. Sari, N. P. R., Bendesa, I. K. G., \& Antara, M. (2019). The influence of quality of work life on employees' performance with job satisfaction and work motivation as intervening variables in starrated hotels in Ubud tourism area of Bali. Journal of Tourism and Hospitality Management, 7(1), 7483. https://doi.org/10.15640/jthm. v7n1a8

56. Schaubroeck, J., Lam, S. S. K., \& Peng, A. C. (2011). Cognitionbased and affect-based trust as mediators of leader behavior influences on team performance. Journal of Applied Psychology, 96(4), 863-871. https://doi. org/10.1037/a0022625
57. Schneider, B., Ehrhart, M. G., \& Macey, W. H. (2013). Organizational climate and culture. Annual review of psychology, 64, 361-388. https:// doi.org/10.1146/annurevpsych-113011-143809

58. Shaw, W. H. (2005). Business ethics. Belmont, CA: Thomson Wadsworth.

59. Sirgy, M. J., Efraty, D., Siegel, P., \& Lee, D. J. (2001). A new measure of quality of work life (QWL) based on need satisfaction and spillover theory. Social Indicators Research, 55(3), 241-302. http://dx.doi. org/10.1023/A:1010986923468

60. Sun, W., Xu, A., \& Shang, Y. (2014). Transformational leadership, team climate, and team performance within the NPD team: Evidence from China. Asia Pacific Journal of Management, 31(1), 127-147. http://dx.doi. org/10.1007/s10490-012-9327-3

61. Supriyanto, A. S., Ekowati, V. M., Idris, I., Susminingsih, S., \& Iswanto, B. (2020). Leadership styles as a predictor of the voluntary work behaviors of bank employees. IJEM International Journal of Economics and Management, 14(1), 1-11. Retrieved from http://repository. uin-malang.ac.id/6333/

62. Valldeneu, M., Ferràs, X., \& Tarrats-Pons, E. (2021). Transformational behaviors:
Increasing work engagement in multinational environments. Problems and Perspectives in Management, 19(2), 519-527. http://dx.doi.org/10.21511/ ppm.19(2).2021.41

63. Van der Berg, Y., \& Martins, N. (2013). The relationship between organisational trust and quality of work life. SA Journal of Human Resource Management, 11(1), 1-13. https://doi.org/10.4102/sajhrm. v11il.392

64. Walton, R. E. (1975). Improving the quality of work life. Harvard Business Review, 52(3), 12-16.

65. Wang, G., Oh, I., Courtright, S. H., \& Colbert, A. E. (2011). Transformational leadership and performance across criteria and levels: a meta-analytic review of 25 years of research. Group \& Organization Management, 36(2), 223-270. http://dx.doi. org/10.1177/1059601111401017

66. Wisnom, M., \& Gallagher, K. (2018). Quality of work life in the resort spa industry. International Journal of Spa and Wellness, 1(3), 159-177. http://dx.doi.org/10.1080 /24721735.2019.1596658

67. Yue, C. A., Men, L. R., \& Ferguson, M. A. (2019). Bridging transformational leadership, transparent communication, and employee openness to change: The mediating role of trust. Public Relations Review, 45(3), 101779. https://doi.org/10.1016/j.pubrev.2019.04.012 


\section{APPENDIX A}

Table A1. Convergent validity and discriminant validity: Outer loadings and cross-loadings

\begin{tabular}{|c|c|c|c|c|}
\hline \multirow{2}{*}{ Indicators/items } & \multirow{2}{*}{ Outer loadings } & \multicolumn{3}{|c|}{ Cross-loadings } \\
\hline & & QWL & $\mathrm{TL}$ & CT \\
\hline QWL1 & 0.756 & 0.756 & 0.375 & 0.256 \\
\hline QWL3 & 0.719 & 0.719 & 0.385 & 0.317 \\
\hline QWL4 & 0.601 & 0.601 & 0.338 & 0.219 \\
\hline QWL5 & 0.810 & 0.810 & 0.378 & 0.408 \\
\hline QWL6 & 0.810 & 0.810 & 0.398 & 0.271 \\
\hline QWL7 & 0.761 & 0.761 & 0.356 & 0.221 \\
\hline QWL8 & 0.827 & 0.827 & 0.441 & 0.307 \\
\hline QWL9 & 0.695 & 0.695 & 0.341 & 0.222 \\
\hline QWL10 & 0.813 & 0.813 & 0.501 & 0.391 \\
\hline QWL11 & 0.783 & 0.783 & 0.466 & 0.176 \\
\hline QWL12 & 0.720 & 0.720 & 0.349 & 0.139 \\
\hline QWL13 & 0.827 & 0.827 & 0.404 & 0.268 \\
\hline QWL14 & 0.815 & 0.815 & 0.336 & 0.422 \\
\hline QWL15 & 0.833 & 0.833 & 0.481 & 0.361 \\
\hline QWL16 & 0.749 & 0.749 & 0.439 & 0.477 \\
\hline QWL17 & 0.707 & 0.707 & 0.376 & 0.299 \\
\hline QWL18 & 0.846 & 0.846 & 0.492 & 0.446 \\
\hline QWL19 & 0.849 & 0.849 & 0.470 & 0.401 \\
\hline QWL20 & 0.795 & 0.795 & 0.530 & 0.408 \\
\hline QWL22 & 0.728 & 0.728 & 0.479 & 0.379 \\
\hline QWL23 & 0.745 & 0.745 & 0.378 & 0.379 \\
\hline QWL24 & 0.737 & 0.737 & 0.387 & 0.406 \\
\hline QWL25 & 0.767 & 0.767 & 0.432 & 0.320 \\
\hline QWL26 & 0.618 & 0.618 & 0.346 & 0.293 \\
\hline QWL28 & 0.738 & 0.738 & 0.328 & 0.190 \\
\hline QWL29 & 0.655 & 0.655 & 0.381 & 0.253 \\
\hline QWL31 & 0.677 & 0.677 & 0.404 & 0.226 \\
\hline QWL32 & 0.677 & 0.677 & 0.353 & 0.466 \\
\hline QWL34 & 0.701 & 0.701 & 0.385 & 0.527 \\
\hline TL1 & 0.754 & 0.303 & 0.754 & 0.423 \\
\hline TL2 & 0.829 & 0.395 & 0.829 & 0.474 \\
\hline TL3 & 0.849 & 0.420 & 0.849 & 0.612 \\
\hline TL4 & 0.870 & 0.536 & 0.870 & 0.483 \\
\hline TL5 & 0.716 & 0.239 & 0.716 & 0.383 \\
\hline TL6 & 0.816 & 0.567 & 0.816 & 0.427 \\
\hline TL7 & 0.820 & 0.525 & 0.820 & 0.549 \\
\hline CT1 & 0.805 & 0.287 & 0.481 & 0.805 \\
\hline CT2 & 0.843 & 0.310 & 0.471 & 0.843 \\
\hline СТ3 & 0.896 & 0.340 & 0.586 & 0.896 \\
\hline CT4 & 0.827 & 0.537 & 0.476 & 0.827 \\
\hline
\end{tabular}

